\title{
ABO and Rhesus Blood Group Distribution among Patients Attending Venereal Diseases Clinics
}

\author{
C. B. S. SCHOFIELD
}

\author{
From the Department of Venereology, c/o Ruchill Hospital, Glasgow
}

In one of the earliest papers on blood groups in disease Alexander (I92I), while investigating malignancy in Dundee, used as controls 50 cases of 'active syphilis', together with a like number of normal subjects and of patients with tuberculosis. $\mathrm{He}$ did not find any significant differences, and the frequencies of the 'active syphilis' group and the normals were almost identical. Apart from Poehlmann (1934), who investigated 300 patients with positive Wassermann reactions and found them to have the same $\mathrm{ABO}$ blood group distribution as among the general Munich population, there would not appear to be any published investigations into the distribution of blood groups in venereal diseases, and this investigation was planned to find out if there were any differences in the commoner conditions for which patients attend a venereal diseases clinic.

\section{Present Investigation}

Information as to the $\mathrm{ABO}$ and Rhesus blood groups of patients attending the clinics at Newcastle and Tynemouth between July 1956 and October 1958, together with clinical manifestations and sex, were recorded on punch-cards for later analysis.

Controls for the ABO blood groups for the Newcastle upon Tyne Hospital Region already exist. Roberts (I953), using material supplied by the Regional Blood Transfusion Service, analysed a total of 54,579 record cards of blood donors for ABO groups. The frequencies he found are as follows: O, $49 \cdot 484 \%$; A, $38.627 \%$; , $9 \cdot 126 \% ; \mathrm{AB}, 2.763 \%$, and these figures have been used in this investigation, but unfortunately there is no similar control for the Rhesus (D) distribution in this area.

\section{Results}

2,575 sera were tested, I,63I $(63 \%)$ from men

Received September 29, 1965. and $944(37 \%)$ from women. Approximately $55 \%$ of the patients were suffering from syphilis, $14.5 \%$ from gonorrhoea, $13.5 \%$ from non-gonococcal urethritis, while the remainder (about $17 \%$ ) were without evidence of venereal disease (NVD). The frequency distributions of the blood groups and their incidence relative to one another for these main classifications are set out in Table I.

Although there are some differences in blood group distribution, these differences are without statistical significance. The vast majority of all female patients and those men with syphilis were native to Tyneside, while a number of men with gonorrhoea and non-gonococcal urethritis were peripatetic.

In view of the possibility that the syphilis group was not homogeneous, it was broken down into the anatomical diagnoses.

There was no significant difference in the ABO distribution among patients with contagious syphilis, neuro-syphilis, or benign tertiary syphilis, or of any of the clinical entities within these groups, but when patients with cardiovascular syphilis were divided arbitrarily into those with aortic valvular damage (aortic incompetence) and those without (aortitis and aneurysms of the aorta), as shown in Table II, it was found that the excess of male patients with blood group $A$ and suffering from aortitis and/or aneurysms of the aorta had significant statistical difference when compared with (a) the controls, (b) with women having the same complaint, and (c) with men and women suffering from aortic incompetence.

While there was a wide range in the incidence of Rhesus positives, the differences were not significant in any entity.

\section{Discussion}

The $\mathrm{ABO}$ frequencies of men and women, though not parallel, do not differ significantly from the 
TABLE I

ABO AND RHESUS-D BLOOD GROUP FREQUENCIES AND RELATIVE INCIDENCE OF MAIN CLASSIFICATIO OF PATIENTS IN THIS INVESTIGATION

\begin{tabular}{|c|c|c|c|c|c|c|c|c|c|c|}
\hline \multirow{2}{*}{ Diagnosis } & \multirow{2}{*}{ Sex } & \multirow{2}{*}{ Total } & \multirow{2}{*}{$\mathrm{O}$} & \multirow{2}{*}{ A } & \multirow{2}{*}{ B } & \multirow{2}{*}{$\mathrm{AB}$} & \multirow{2}{*}{ Rhesus (D) } & \multicolumn{3}{|c|}{ Relative Incidence } \\
\hline & & & & & & & & $A: O$ & $\mathrm{~B}: \mathrm{O}$ & $\mathrm{A}: \mathrm{B} \frac{\mathrm{C}}{\mathrm{O}}$ \\
\hline $\begin{array}{l}\text { Syphilis } \\
\text { Gonorrhoea } \\
\text { Non-gonococcal } \\
\text { urethritis } \\
\text { No venereal disease }\end{array}$ & $\begin{array}{l}M \\
F \\
M \\
F \\
M \\
F^{*} \\
M \\
F\end{array}$ & $\begin{array}{r}732 \\
694 \\
299 \\
75 \\
292 \\
53 \\
308 \\
122\end{array}$ & $\begin{array}{r}352(48) \\
362(52) \\
139(46) \\
37(49) \\
139(48) \\
18(34) \\
156(51) \\
54(44)\end{array}$ & $\begin{array}{r}294(40) \\
269(39) \\
122(41) \\
34(45) \\
116(40) \\
28(53) \\
113(37) \\
58(48)\end{array}$ & $\begin{array}{l}67(9) \\
52(7) \\
31(10) \\
4(5) \\
26(9) \\
7(13) \\
27(9) \\
9(7)\end{array}$ & $\begin{array}{r}19(3) \\
11(2) \\
7(2) \\
0 \frac{1}{1} \\
11(4) \\
0 \frac{(4)}{12(4)} \\
1 \text { (I) }\end{array}$ & $\begin{array}{r}581(79) \\
559(84) \\
239(80) \\
60(80) \\
233(80) \\
42(79) \\
246(80) \\
101(83)\end{array}$ & $\begin{array}{l}\mathbf{r} \cdot 07 \\
0.95 \\
\mathbf{I} \cdot \mathbf{1} 2 \\
\mathbf{1} \cdot \mathbf{1} 7 \\
\mathbf{1} \cdot 07 \\
2 \cdot 0 \\
0.93 \\
\mathbf{1} \cdot 37\end{array}$ & $\begin{array}{l}1 \cdot 03 \\
0.78 \\
1 \cdot 21 \\
0.47 \\
1 \cdot 04 \\
2 \cdot 1 \\
0.94 \\
0.9\end{array}$ & $\begin{array}{l}1.04 \overline{0} \\
1.22 \\
0.930 \\
2.01 \\
1.050 \\
0.95 \\
0.990 \\
1.52\end{array}$ \\
\hline Totals & & 2575 & $1257(49)$ & $1034(40)$ & $223(9)$ & & $2061(80)$ & $1 \cdot 05$ & 0.96 & $\mathrm{I} \cdot 09$ \\
\hline
\end{tabular}

Percentages are given in parentheses.
* Consorts of men suffering from non-gonococcal urethritis.

TABLE II

ABO AND RHESUS (D) BLOOD GROUP DISTRIBUTION IN CARDIOVASCULAR SYPHILIS, WITH RELATIVE A INCIDENCE, AND SIGNIFICANCE OF DIFFERENCE FROM CONTROLS

\begin{tabular}{|c|c|c|c|c|c|c|c|c|c|c|c|}
\hline $\begin{array}{l}\text { Type of Cardio- } \\
\text { vascular Syphilis }\end{array}$ & Sex & Total & $\mathbf{O}$ & $\mathbf{A}$ & $\mathbf{B}$ & AB & Rhesus (D) & Rel. A:O & $x^{2}$ & $\mathrm{n}$ & $\mathbf{p}$ \\
\hline $\begin{array}{l}\text { Aortic } \\
\text { incompetence } \\
\text { Aortitis and } \\
\text { aneurysms }\end{array}$ & $\begin{array}{l}\mathbf{M} \\
\mathbf{F} \\
\mathbf{M}\end{array}$ & $\begin{array}{l}96 \\
28 \\
54 \\
41\end{array}$ & $\begin{array}{l}49(5 I) \\
20(71) \\
17(32) \\
25(62)\end{array}$ & $\begin{array}{r}38(40) \\
8(29) \\
30(56) \\
13(31) \\
\end{array}$ & $\begin{array}{l}7(8) \\
5(8) \\
2(5)\end{array}$ & $\begin{array}{l}2(2) \\
2(4) \\
1(2)\end{array}$ & $\begin{array}{l}81(84) \\
18(64) \\
39(72) \\
33(80)\end{array}$ & $\begin{array}{l}0.99 \\
0.65 \\
2.26 \\
0.67\end{array}$ & $\begin{array}{l}0 \cdot 006 \\
2 \cdot 296 \\
6 \cdot 84 \\
I \cdot 052\end{array}$ & $\begin{array}{l}\mathbf{I} \\
\mathbf{I} \\
\mathbf{I} \\
\mathbf{I}\end{array}$ & $\begin{array}{l}\text { p } 0.9 \\
\text { p } 0.1 \\
\text { p } 0.01 \\
\text { p } 0.3\end{array}$ \\
\hline Totals & & 219 & I I I (5I) & $87(4 I)$ & $14(6)$ & $5(2)$ & $171(78)$ & $1 \cdot 03$ & 0.002 & I & po.95 \\
\hline
\end{tabular}

Percentages are given in parentheses.

control frequencies, while the Rhesus (D) incidence is similar throughout. From this one can infer that any selection of patients has been unbiased, and that the 'clinic population' is representative of the community in this respect. All the numbers are small, especially so for the investigation of blood group frequencies. Bias, unwittingly introduced by any form of selection, as one is bound to have with small numbers, gives rise to apparent differences such as we initially found in the Rhesus incidence in non-gonococcal urethritis: these were ironed out later when larger numbers of patients were included.

There is a need for more and larger surveys to confirm or refute the finding of an excess of patients with blood group $\mathrm{A}$, and corresponding deficiency in Group $\mathrm{O}$, among those men suffering from aortitis and/or aneurysm of the aorta, which might be considered less serious manifestations of cardiovascular syphilis than aortic incompetence. This was the only statistically significant finding among the many entities of syphilis that were investigated.

It is of interest that Murray (I96I), comparing healthy elderly people (members of 'Over 6os' Clubs) with geriatric patients in hospital, found among the men a significant decrease in group $\mathrm{O}$ with a corresponding increase in group $\mathrm{A}$, in the healthy as compared with those in hospital, that dif not occur among the women. The reasons for these similar findings in people of about the same age group are not known.

\section{Summary and Conclusions}

The ABO and Rhesus (D) blood groups were examined on 2,575 patients attending venerea diseases clinics. Of these, $63 \%$ were men, and $37 \%$ were women. $55 \%$ were suffering from syphilis, either acquired or congenital, $28 \%$ had urethritis gonococcal or otherwise, and the remaining 17 of had no venereal disease.

The $\mathrm{ABO}$ frequencies for the totals and for men and women of the classifications mentioned above were similar to the controls for the area. The Rhesus-D frequencies were similar to one another.

The syphilis material did not reveal any significar differences until it was broken down to its basis entities, when an excess of patients with blood group A was found among men suffering from aortitis and/or aneurysms of the aorta $\left(\chi^{2}=6 \cdot 8\right.$ क $\mathrm{n}=\mathrm{I}, \mathrm{p}=0.01$ ). There was no significant differengeg 
in the incidence of the Rhesus-D in any of the entities.

It is noted that a similar finding has been reported when comparing healthy elderly men with male patients in a geriatric unit, there being no noted difference between healthy elderly women and those in hospital.

I wish to thank Dr. B. E. Tomlinson and his staff for carrying out the $\mathrm{ABO}$ and Rhesus-D blood grouping, Dr. G. McCoull and the late Dr. C. G. Millman for sending blood from patients in their care, the staff of the
Department of Venereology, Newcastle upon Tyne for their co-operation, Dr. Sheilagh Murray for her help and criticism, and Dr. W. V. Macfarlane for permission to publish.

\section{REFERENCES}

Alexander, W. (192I). An inquiry into the distribution of the blood groups in patients suffering from 'malignant disease'. Brit. $\mathcal{F}$. exp. Path., 2, 66.

Murray, $\mathrm{S}$. (I96I). ABO groups and Rh genotypes in the elderly. Brit. med. F., 2, 1472.

Poehlmann, A. (1934). Blutgruppe, serologische Konstitution und Wassermannsche Reaktion. Münch. med. Wschr., 81, 625.

Roberts, J. A. F. (1953). An analysis of the ABO blood-group records of the North of England. Heredity, 7, 361. 